\title{
Whole transcriptome sequencing and biomineralization gene architecture associated with cultured pearl quality traits in the pearl oyster, Pinctada margaritifera
}

\author{
J. Le Luyer ${ }^{1}$, P. Auffret ${ }^{1}$, V. Quillien ${ }^{1}$, N. Leclerc ${ }^{1}$, C. Reisser ${ }^{1}$, J. Vidal-Dupiol ${ }^{1,2}$ and C.-L. Ky ${ }^{1 *}$
}

\begin{abstract}
Background: Cultured pearls are unique gems produced by living organisms, mainly molluscs of the Pinctada genus, through the biomineralization properties of pearl sac tissue. Improvement of $P$. margaritifera pearl quality is one of the biggest challenges that Polynesian research has faced to date. To achieve this goal, a better understanding of the complex mechanisms related to nacre and pearl formation is essential and can now be approached through the use of massive parallel sequencing technologies. The aim of this study was to use RNAseq to compare whole transcriptome expression of pearl sacs that had producing pearls with high and low quality. For this purpose, a comprehensive reference transcriptome of $P$. margaritifera was built based on multi-tissue sampling (mantle, gonad, whole animal), including different living stages (juvenile, adults) and phenotypes (colour morphotypes, sex).

Results: Strikingly, few genes were found to be up-regulated for high quality pearls ( $n=16)$ compared to the upregulated genes in low quality pearls $(n=246)$. Biomineralization genes up-regulated in low quality pearls were specific to prismatic and prism-nacre layers. Alternative splicing was further identified in several key biomineralization genes based on a recent $P$. margaritifera draft genome.

Conclusion: This study lifts the veil on the multi-level regulation of biomineralization genes associated with pearl quality determination.
\end{abstract}

Keywords: Pinctada margaritifera, Biomineralization, Pearl quality, Pearl sac, RNA-seq

\section{Background}

The bivalve Pinctada margaritifera var. Cumingii is a species of great economic interest in French Polynesia. Its aquaculture and asscociated pearl industry is the second most important source of income there, just after tourism. Cultured pearl production requires two distinct animals. A small piece of graft mantle tissue is dissected from a sacrificed donor oyster and inserted with a round bead of nacre (a nucleus, made of mussel shell) into the recipient oyster gonad $[1,2]$. If the graft is not rejected and the recipient oyster survives the grafting operation,

\footnotetext{
* Correspondence: chinky@ifremer.fr

'Ifremer, UMR 241 Ecosystèmes Insulaires Océaniens (EIO), Labex Corail,

Centre Ifremer du Pacifique, BP 49, 98719 Tahiti, French Polynesia

Full list of author information is available at the end of the article
}

the implanted mantle tissue will grow to completely surround the nucleus and form a "pearl sac", capable of secreting biomaterial layers (calcite and aragonite) around the nucleus [3]. After 15 to 24 months of culture, pearls are harvested and usually sorted according to six main quality traits: size, shape, colour, surface complexion, lustre and grade [4]. Less than $5 \%$ of the produced pearls can be classified as grade $\mathrm{A}$, which corresponds to the best quality according to the local regulatory quality standards [5]. Average export price of cultured pearls in French Polynesia has fallen dramatically over the past decade, mainly due to a combination of factors including overproduction; hence quantity has been favoured to the detriment of quality. The improvement of cultured pearl quality is an imperative aspect of a pearl farm's 
sustainability and as one of the biggest challenges that research is facing in French Polynesia.

Factors affecting pearl quality have diverse and non-exclusive origins including genetics, environment and/or genotype-by-environment interaction (GEI) [6, 7]. This is further complexified in the Pinctada transplant model because of the phenotype transmission from the donor oyster to the recipient oyster, their interplay, and their interaction with the environment. One particularity of this animal model is the chimera system attributed to the pearl sac tissue, whose interaction between Genome $_{\text {Donor }} \times$ Genome $_{\text {Host }}$ has a significant effect on pearl quality $[8,9]$. Our understanding of genomes interaction benefited from xenograft experiments $(P$. maxima $\mathrm{x} P$. margaritifera) showing that donor mantle tissue is the main regulator of a predefined set of biomineralization related genes [9]. A recent study in P. margaritifera, based on controlled bi-parental crosses and the F1 generation, demonstrated heritability ( $h^{2}$ from 0.21 to 0.37$)$ for nacre weight and thickness, pigmentation darkness and colour, surface defects and grade, signifying a donor oyster effect with a genetic basis, although there were also important interaction components [10]. Previous studies reported that location, temperature and food availability [11-13], pearl rotation [14], donor oyster genotype [4, 9, 15-18], age [19], position of graft mantle [20] and contamination during the graft operation and/ or graft operator skills [21] are all determinants of final pearl quality and do not necessarily affect similar traits.

Various genomic approaches have been applied in pearl oyster with the objectives of identifying key candidate markers related to pearl quality traits. For instance, Lemer et al. [22] identified a set of genes differentially expressed between two mantle colour phenotypes (black P. margaritifera phenotypes and full albino individuals), using a suppressive and subtractive hybridization (SSH) method. In silver-lipped oyster (Pinctada maxima), genetic association analyses has permitted the identification of QTLs linked to pearl surface complexion and colour as well as genetic associations of regions and markers for pearl size, weight, colour and surface complexion $[23,24]$. Transcriptome-wide and proteomic approaches have also been used to characterize the pool of genes expressed during pearl formation and to discriminate markers preferentially associated with nacreous and/or prismatic layers. Studies in the Japanese pearl oyster (Pinctada fucata) showed that the genes msi60 and aspein from the mantle tissue were up-regulated in low quality pearls compared to high quality groups, while the expression of the msi30 gene from the pearl sac tissue was up-regulated in high quality pearls [26, 27]. Finally, a recent study on $P$. margaritifera revealed that shematrin5 and 9, prismalin and aspein encoding genes were up-regulated in the pearl sacs of individuals producing low pearl surface quality [28]. Studies have been limited to relatively few candidate genes, however, and an overall evaluation of the actors involved in pearl quality remains to be conducted.

The aim of our present study was to identify key genes involved in the regulation of pearl quality through a comparative RNA-seq analysis of pearl sacs producing high and low quality cultured pearls (Fig. 1). We constructed a new comprehensive multi-tissue transcriptome assembly, covering several developmental stages, colour morphotypes and tissue origins, which will be useful for further transcriptomic studies in $P$. margaritifera. Furthermore, based on a recently assembled draft genome of $P$. margaritifera, we successfully explored the possibility that alternative gene splicing events are involved in the regulation of biomineralization processes.

\section{Results}

\section{Transcriptome assembly}

The raw transcriptome assembly contained 541,184 transcripts. After filtering for redundancy and functionality, we retained a total of 41,075 transcripts (assembly metrics given in Table 1). Transcriptome completeness evaluation indicated that $90.6 \%$ of the highly conserved single-copy metazoan genes $(n=978)$ were present in our transcriptome $(89.8 \%$ are complete and in a single-copy). Similarly, mean mapping rate reached $66.31 \pm 1.72 \%$ with negligible differences in sample condition. Both the transcriptome completeness and satisfactory mapping rate suggest that the several steps of filtering applied did not have major impact on the overall transcriptome. Functional annotation identified a total of 33,532 transcripts $(81.5 \%)$ with at least one match with deposited sequences (Table 1).

\section{Differential expression in biomineralization-related genes} We found a total of 262 differentially expressed genes (DEGs), with 246 up- and 16 down-regulated genes in low quality pearls (Fig. 2; Additional file 1: Table S3). Out of the 262 DEGs, 216 (82.24\%) had at least one match with known protein sequences (Additional file 1: Table S3). Finally, only 114 of the DEGs (43.5\%) had at least one associated GO term. GO analysis revealed enrichment for some relevant functions involved in pearl formation, including oxidoreductase activity (GO:0016491), peptidase inhibitor activity (GO:0030414), serine-type peptidase activity (GO:0008236), chitin binding (GO:0008061) and copper ion binding (GO:0005507). The GO enrichment analysis is summarized in Additional file 1: Figure S1.

We identified several biomineralization genes discriminating high and low quality pearls (Fig. 3; Additional file 1: Table S3). Most of these genes are characteristic of prismatic and prism-nacre layers [29] and were found up-regulated in low quality pearls. The blue mussel shell 


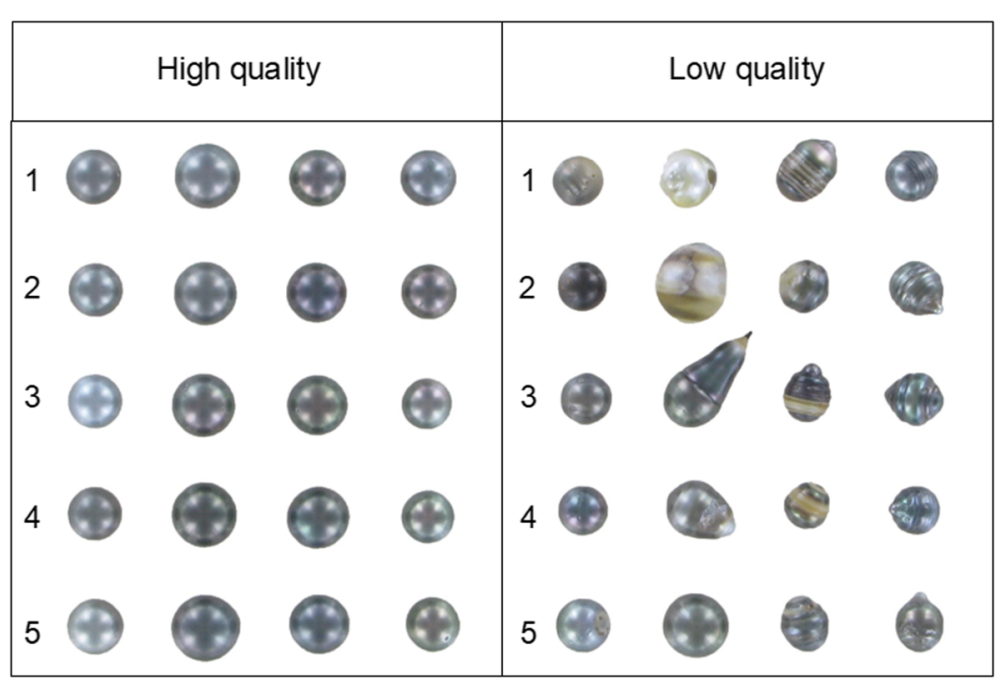

Fig. 1 High and low quality cultured pearl samples from P. margaritifera. Each row within each condition (high or low quality), represents a specific pool ( $n=4$ cultured pearls / pool / condition). Numbers represent pools by condition (high or low pearl quality). High quality pearls concerned pearls with maximum two or three spots (C grade and above), showing lustre, without any circle and calcitic imperfection on its surface. Low quality pearls (D1 and D2 grades) corresponded to pearls with damaged surfaces, but D1 grade pearls also had lustre and colour that was absent in D2

protein-like (BMSP-like) coding gene is the single biomineralization gene up-regulated in high quality pearls. BMSP-like shares strong homology with the P. fucata pif-177 gene and is notably involved in determining the polymorph of $\mathrm{CaCO}_{3}$ [30]. We also identified Gypsy and Jockey-family transposable elements up-regulated in high quality pearls (Additional file 1: Table S3). The qPCR analysis shows that the individual relative expression of the four biomineralization-related genes analysed is in accordance with results from pool RNA-seq data (Additional file 1: Figure S2). We found the MP10,

Table 1 Transcriptome assembly, annotation statistics and differential expression results

\begin{tabular}{ll}
\hline Transcriptome statistics & \\
Raw number of contigs & 541,184 \\
Total number of contigs & 41,075 \\
Percent GC & 39.1 \\
Contigs N50 (bp) & 2087 \\
Total assembled bases & $57,671,860$ \\
Median contig length (bp) & 958 \\
Average contig length (bp) & 1404.06 \\
Annotation & \\
Contig with P. fucata match (e-value 10 & \\
Contig with C. gigas match (e-value 10 & $32,489(19,850)^{\mathrm{a}}$ \\
Contig with Uniprot-Swissprot match (e-value 10-4) & $27,568(12,837)^{\mathrm{a}}$ \\
Contig with GO identifier annotation ${ }^{\mathrm{b}}$ & 18,163 \\
\hline Best hit & \\
${ }^{\mathrm{b}}$ Based on Uniprot-Swissprot blastX results &
\end{tabular}

shematrin-9 and aspein up-regulated in low quality pearls ( $p$-value $<0.001)$ while no significant difference was observed for pif-177 ( $\mathrm{p}$-value $=0.012$ ).

\section{Different alternative splicing in biomineralization-related genes}

We found a total of 28 transcripts showing significant differential splicing $(F D R<0.001)$. Several of these genes are known to be involved in biomineralization processes: pif, aspein, pwap and wdf18. For aspein, high quality pearls show lower exon 1 usage (Fig. 4). This specific exon overlaps with the promoter domain of the transcript while the exon 2 codes for the D-domain rich in Asp amino acid that gives the aspein protein its crystal binding affinity and its function in regulating crystal growth [26, 31-34]. The GO enrichment analysis identified the peptide biosynthetic process (GO:0043043), amide biosynthetic process (GO:0043604) and translation function (GO:0006412) as enriched for the genes showing different exon usage.

\section{Discussion}

Access to massive parallel sequencing technologies now greatly contributes to the understanding of molecular expression of the phenotype in non-model species. Here, we used a common transcriptomic approach (RNA-seq) to obtain an overview of differences in gene expression and alternative splicing between high and low cultured pearl quality. Recently, RNA-seq has been successfully used to explore genes related to pearl oyster growth and response to environmental stressors (P. fucata) $[35,36]$ and 

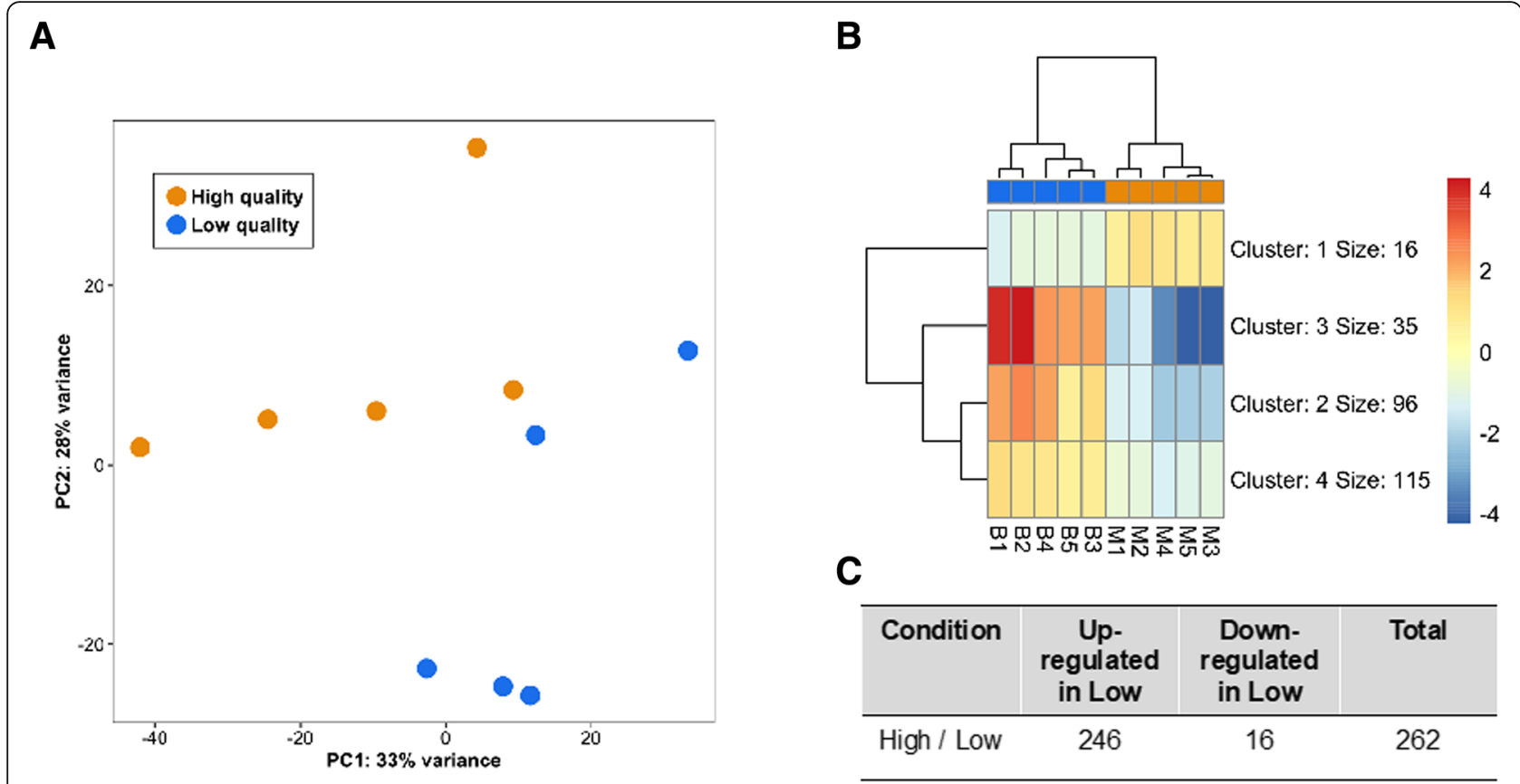

Fig. 2 Genes differentially expressed between P. margaritifera pearl sacs having produced high and low quality pearls: a) Principal component analysis (PCA); b) Heatmap of differentially expressed genes. LogCPM $(+2)$ were computed based on raw counts normalized for library size reported to the mean gene expression over all individuals; and c) Table showing the number of differentially expressed genes

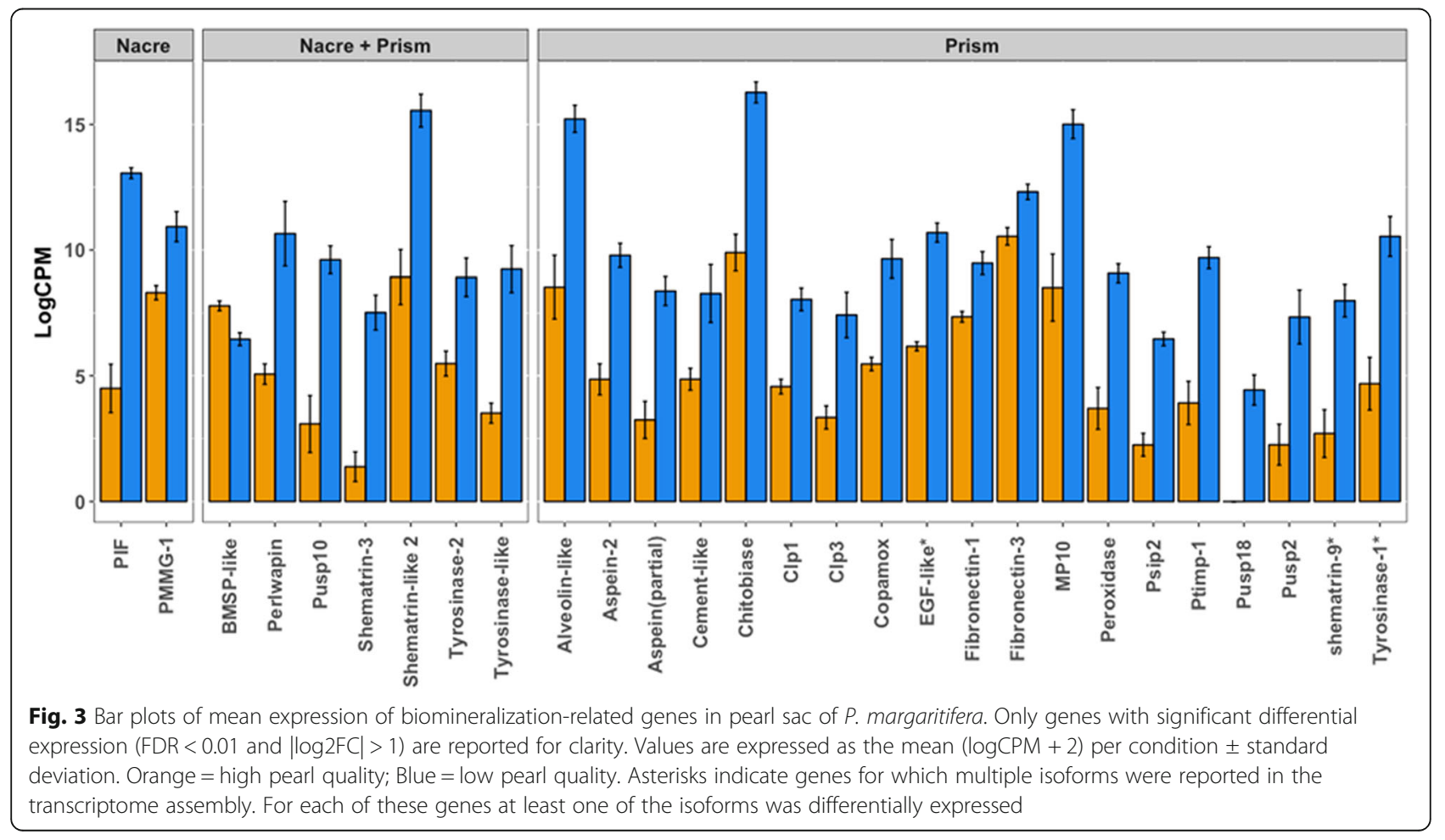




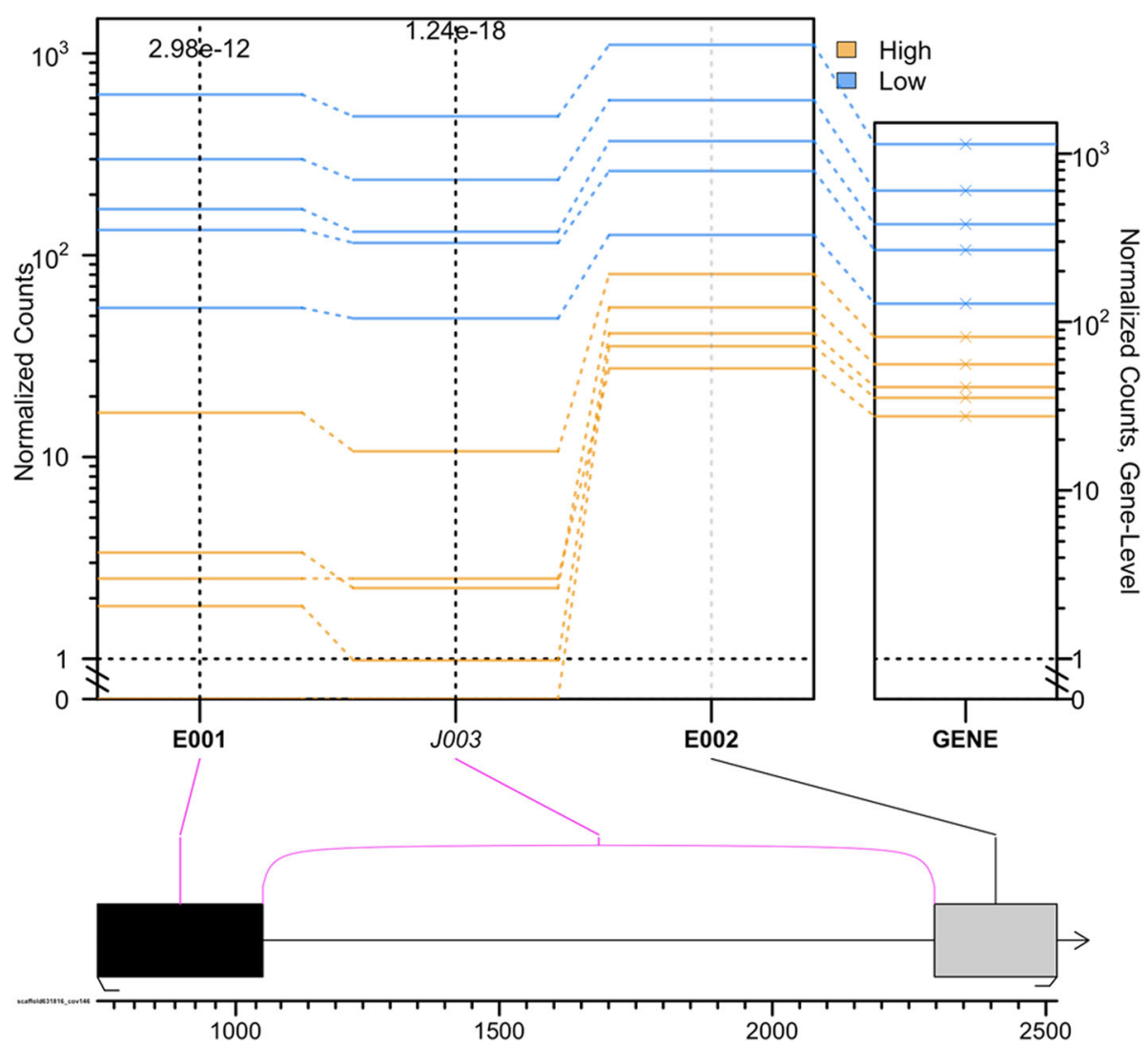

Fig. 4 Splicing event visualization for the aspein gene in the pearl sac of $P$. margaritifera. Normalized counts are plotted for each gene section, either exon (E) or junction (J), and each individual; blue = high quality and orange = low quality. Values in the box plot represent $p$-values (Fisher's test) for each gene section

biomineralization (P. martensii and P. penguin) [37-39]. The use of RNA-seq in $P$. margaritifera for biomineralization related studies has been held back by the relatively limited coverage of previous transcriptome references (Roche 454; [40]) or their reduced tissue representation [41]. Recent work has however completed multi-tissue transcriptome assemblies of four species of pearl oysters including $P$. margaritifera. Yet, unfortunately, sampling did not include pearl sac tissues and to our knowledge assemblies were not made publicly available [42]. The present study provides a comprehensive reference transcriptome for $P$. margaritifera, encompassing whole-body tissue as well as phenotypic variation for a single common tissue (for gonads this was either female or male; for mantle tissue and whole individuals this covered a broad range of shell colour) as well as including individuals of different life stages (juveniles or adults). Even when applying stringent filtering, the satisfactory completeness as well as good individuals mapping rates and high gene content conservation with the closely related species $P$. fucata (78\% overlap) all suggested that this new reference transcriptome should prove itself a useful genomic resource for a broad range of future transcriptomic research for $P$. margaritifera.

\section{Complex responses of biomineralization genes are associated with pearl quality}

The pearl sacs producing low quality pearls were characterized by a higher activity of prismatic layer-specific genes. Among the differentially expressed genes, aspein and shematrin-9 were found to be up-regulated in low quality pearl RNA-seq pools, as well as being validated by individual qPCR, which is consistent with previous candidate gene expression work [28]. The present study also provides a novel set of biomarkers involved in the biomineralization process, such as perlwapin and BMSP-like genes, and supports previous findings showing deep conservation of biomineralization genes within molluscs [43-45].

A considerable number of studies have focused on the identification of genes involved in aragonite and/or calcite formation in pearl oyster species and other bivalves capable of shell mineralisation [20, 22, 46, 47, 48-54]. Nonetheless, it has proven difficult to extrapolate the role 
of key actors involved in determining cultured pearl quality across studies. In P. maxima, QTL analysis suggested that the expression of pearl phenotypes have a complex genetic architecture and under the control of many genes located in several genome regions [25]. It is reasonable to hypothesize that contrasting results in the expression of biomineralization genes might result from the pleiotropic effect of biomineralization genes and/or major differences in the design of these different studies (genetic background, geographical locations, pearl grades sampled, time of sampling post-graft, environmental factors and tissue-analysed). For instance, differences in response of the pearlin gene, a gene commonly used to monitor biomineralization, have been observed in both graft and pearl sac tissues under similar environmental stress conditions (temperature and food availability) [12, 50]. Similarly, expression of key biomineralization genes such as nacrein or pif in pearl sacs was clearly dependent on the time of sampling post-graft $[12,28]$. Pif-related genes are particularly interesting because they directly controlled crystal growth during an in vitro experiment [55], yet the clear connexion between pif-related gene expression and pearl phenotypes remains unclear. The present study showed that neither pif nor pif-177 were differentially expressed between high and low pearl quality despite these genes having already been correlated with pearl weight $(\mathrm{Rho}=$ $0.259 ; \quad p$-value $=0.01$ ) and pearl quality 3 months post-graft in previous studies on $P$. margaritifera $[28,51]$. Inversely, the BMSP-like gene, a gene related to the pif family [52], was up-regulated in high quality pearls. Clearly, further studies will be needed to unravel the complex role of pif-related genes during the different stages of pearl formation. Nevertheless, this study supports previous findings on the role of aspein and shematrin 9 genes in controlling pearl quality, independently of geographical location or time of post-graft sampling. Inversely, pif gene (pif-177, pif and BMPS-like) expression was not consistent with previous studies and suggests that pif expression variation is strongly time-dependent, which could be the basis of the complex role of the pif-related gene family in pearl biomineralization.

Different exon usage plays a role in shaping pearl quality Genes and related proteins involved in biomineralization have complex structures and often require post-translational modifications and proteolytic cleavages [53]. Alternative splicing in biomineralization-related genes has already been suggested by the presence of numerous isoforms for spicule matrix protein (SpSMs) coding gene in sea urchin [54]. In the present study, four biomineralization-related genes, pif, aspein, perlwapin and wfd18, were found to have significant differences in exon usage, and were all also differentially expressed between low and high pearl quality. The present study could not, however, assess whether the control of exon usage is under epigenetic and/or genetic control. In an effort to reduce the variability inherent to the complex determination of pearl quality, our sampling design only included pooled samples from a single geographic location and mixed several pearl defect types. However, broadening our results on splicing events to the individual level and specific defect types could enable us to redefine the link between biomineralization gene architecture and pearl quality traits.

\section{Transposable elements might be involved in the regulation of cultured pearl quality}

Strikingly, this study only identified a few genes as being up-regulated in high quality pearls $(n=16)$ compared to the number of up-regulated genes in low quality pearls $(n=246)$. Among these up-regulated genes, there was a surprisingly high representation of transposable element(TE) related genes ( $n=3$ out of 7 annotated genes) including long-transposable elements (LTR) of the Gypsy and Jockey families. Recent studies in humans and plants suggest that TEs and TEs insertion are effective regulators of gene expression and alternative splicing events [56-58]. Furthermore, it has been shown that both tandem repeats (TRs) and TEs are intimately linked with TRs derived from younger/more active TEs [59]. As an example, a study in maize supports the results of specific centromeric TRs originating from Ty3/gypsy retrotransposons [60]. From an evolutionary perspective, genes involved in biomineralization are structurally complex and often characterized by the presence of numerous TRs [61]. It is thus plausible that control of tandem repeat formations might result from TE insertion $[62,48]$. However, by which mechanisms TEs (specifically Gypsy and Jockey family TEs) are involved in pearl quality remains to be elucidated. Further studies correlating TE insertion with the structure of transcripts (such as aspein), considering the specific genotypic background, should provide useful information that will help unravel the complex regulation of cultured pearl quality traits.

\section{Conclusions}

This study successfully made it possible to: 1) identify genes whose expression in pearl sacs was associated with cultured pearl quality in $P$. margaritifera, and 2) highlight other putative regulation levels for pearl quality determination through alternative splicing and $\mathrm{TE}$ regulation. Among the genes differentially expressed, new candidates were identified for pearl quality (perlwapin, BMSP-like), as were previously described biomarkers (aspein and shematrin-9). The present study also showed, however, that gene expression of some biomarkers previously associated with pearl quality or thickness (pif-177, pif, msi30, pearlin or nacrein), is not 
systematically correlated with pearl quality, suggesting that other factors might be involved. Further studies should focus on time-course experiments from the first stages of mineral deposition until harvest so as to unravel gene expression in the successive biomineralization events and the interplay between environmental and genetic factors in controlling specific quality traits.

\section{Methods}

\section{Transcriptome reference assembly of $P$. margaritifera}

The multi-tissue reference transcriptome was built with tissues obtained from a total of 10 P. margaritifera individuals: gonad tissues $(n=2$, obtained from one male and one female; [41]), whole tissue of 4-month-old juveniles (whole individuals, $\mathrm{n}=2)$ and mantle tissue $(n=6$; Table 1). All animals provided from wild, except for juveniles, which were produced at Ifremer hatchery facilities. For all samples apart from the gonads, total RNA was extracted with TRIZOL Reagent (Life Technologies) at a ratio of $1 \mathrm{ml}$ per $100 \mathrm{mg}$ tissue, following manufacturer's recommendations. RNA quantity/integrity and purity were validated on a Nanodrop (NadoDrop Technologies Inc.) and on a BioAnalyzer 2100 (Agilent Technologies), respectively. RNA was dried in RNA-stable solution (ThermoFisher Scientific) following manufacturer's recommendations and shipped at room temperature to McGill sequencing platform services (Montreal, Canada). TruSeq Sample Prep. (Illumina, San Diego, Ca, USA) RNA libraries were multiplexed $(n=10$ pools by lane) and sequenced by HiSeq4000 100-bp paired-end (PE) sequencing technology. For the gonads, the samples were also sequenced by HiSeq2000 100-bp PE and were downloaded from the SRA database (Bioproject PRJNA229186; see [41] for more information on RNA preparation). Reads were filtered for adapter removal, minimum length ( $\geq 40-\mathrm{bp})$ and minimum quality $(\mathrm{Q}=28)$ using Trimmomatic v0.36 [63]. The retained PE reads were assembled with Trinity v2.4.0 [64] using default parameters with a minimum transcript length of 200-bp. Read quality was assessed before and after read trimming with FastQC v0.11.5 (https://www.bioinformatics.babraham.ac.uk/projects/fastqc/).

Functional and mapping-rate filtering approaches were combined to reduce the redundancy present in the first version of the $P$. margaritifera transcriptome. Briefly, open-reading frames (ORFs) for each transcript were predicted using 'LongOrfs' function implemented in Transdecoder v3.0.1 [58]. Only the transcripts containing an ORF of at least 100 amino acids were kept. Another filtering step included the removal of isoforms with residual expression; hence, only the most expressed isoforms for each gene with a mean mapping rate of 0.5 transcripts per million (TPM) were kept. We used a blastN approach against curated and non-redundant viral, bacterial, archeal, plasmid and fungal RefSeq transcripts databases (Download 19-09-17; ftp:// ftp.ncbi.nlm.nih.gov/refseq/release/) to remove putative contamination. Transcripts matching a reference with an e-value $<10^{-10}$, minimum identity of $75 \%$ and minimum query coverage of $70 \%$ were discarded. Finally, Illumina adapters were screened in the transcriptome using a blastN approach and adapter list (http://omicsoft.com/ downloads/ngs/contamination_list/v1.txt). Assessment of the final transcriptome completeness was conducted with BUSCO v1.1b [65] against the conserved single-copy metazoan genes database $(n=978)$. Each filtering step was validated with TransRate v1.0.3 [66]. Filtered reads were then mapped back on the filtered reference transcriptome to evaluate individual mapping rate with GSNAP v2017-03-17 [67].

For functional annotation, the transcripts were searched against Uniprot-Swissprot [68], Pinctada fucata (http://marinegenomics.oist.jp/pearl/viewer/download?project_id=20) and Crassostrea gigas (ftp://ftp.ncbi.nih.gov/genomes/Crassostrea_gigas/RNA) protein databases using a blastX approach $\left(\mathrm{e}-\mathrm{value}<10^{-4}\right)$ [69]. The best hit results are reported in Table 1.

\section{Animal and tissue sampling}

An experimental graft was realised in order to obtain cultured pearls and their corresponding pearl sacs. For this, a total of 20 pearl oyster donors were used to perform 600 grafts (30 grafts per donor) over a 2-day period, using $2.4 \mathrm{BU}$ nuclei $(7.304 \mathrm{~mm}$ diameter, $0.59 \mathrm{~g}$ weight - Nucleus Bio, Hyakusyo Co., Japan) in December 2015. All grafts were conducted under routine production procedures by a single technician at the Pahai Poe

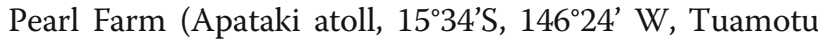
archipelago, French Polynesia) so as to minimize the grafter effect on pearl quality traits described in [70]. Pinctada margaritifera used in this part of the study had been collected as wild spat in December 2013 using commercial collectors in the lagoon of Takapoto atoll (14.32' S, $145^{\circ} 14^{\prime}$ W, Tuamotu archipelago, French Polynesia), two years before the experimental graft took place.

At the time of pearl harvest (18 months after the grafting operation, May 2017) and in order to minimize the contamination by recipient tissues, the gonad was initially excised from the recipient oysters to access to the pearl sac sampling as previosuly described [8]. Next, the pearl sac was incised to remove the cultured pearl, which was then placed in a numbered box for traceability. The pearl sac was kept in a $2.0 \mathrm{ml}$ tube with RNAlater until RNA extraction. A total of 442 pearl sacs were sampled (73.6\% of the total number of oysters grafted). This pearl harvest rate represents the production yield, 
as nucleus rejection and mortality were observed over the entire culture time [21].

Cultured pearl was cleaned and graded as described in [11]. High quality pearls concerned then pearls with maximum two or three spots ( $\mathrm{C}$ grade and above), showing lustre, without any circle and calcitic imperfection on its surface. Low quality pearls (D1 and D2 grades) corresponded to pearls with damaged surfaces, but D1 grade pearls also had lustre and colour that was absent in D2. From the high and low quality pearls, twenty pearl sacs from each group that had produced only green pearls were randomly selected (Fig. 1). Overall, high quality pearls were significantly heavier, with a thicker nacre layer than the low quality pearls (t-test; $p$-value $<0.05)$. Our sampling included 10 donors equally allocated between several pools (either low or high pearl quality, as illustrated in Fig. 1) with the objectives of reducing putative donor effect $[4,15,16,71]$.

\section{RNA extraction and sequencing}

The total RNA extraction procedure was identical to that for the samples used in the transcriptome assembly. For each condition (low or high pearl quality), an equimolar RNA quantity was pooled ( $n=5$ individuals/pool) to give a total of five pools by condition. RNA was dried in RNA-stable solution (ThermoFisher Scientific) following manufacturer's recommendations and shipped at room temperature to McGill sequencing platform services (Montreal, Canada). TruSeq Sample Prep. (Illumina, San Diego, Ca, USA) RNA libraries were multiplexed $(N=10$ pools by lane) and sequenced by HiSeq 4000 100-bp paired-end (PE) sequencing technology.

\section{Differential expression analysis}

Raw reads were trimmed using Trimmomatic v0.36 [63], using similar parameters as for the transcriptome assembly. Only paired-end reads were retained and mapped to the reference transcriptome, using GSNAP v2017-03-17 [67] with default parameters but allowing a minimum mismatch value of 5. Low mapping quality, multi-mapping $(-\mathrm{q} 5)$ and "non-properly paired reads" $(-\mathrm{f} 0 \times 2)$ were removed using Samtools v1.4.1 [72]. A matrix of raw counts was built using HTSeq-count [73]. Low coverage transcripts (CPM < 1 in at least 10 individuals) were removed, resulting in a total of 40,633 transcripts and differential expression was assessed using the DESeq2 $\mathrm{R}$ package [74]. Transcripts were considered significant when FDR $<0.01$ and $|\operatorname{logFC}| \geq$ 1. Gene ontology (GO) enrichment was tested using GOAtools v0.6.5 [75] and the go-basic.obo database (release 2017-04-14) using Fisher's test. Our background list included the ensemble of genes used for differential expression after filtering for low coverage ( $n=40,633$ transcripts). Only GO terms with $p$-value $<0.05$ and including at least three differentially expressed genes were considered. Significant GO enriched terms were used for semantic-based clustering in REVIGO (http://revigo.irb.hr/).

\section{Individual gene expression validation}

RT-qPCR was used to validate the expression patterns in the pearl sac, observed in RNA-seq, for key genes commonly used as markers of pearl quality traits, namely pif-177, aspein, shematrin-9 and the mantle protein 10 (MP10). DNAse tratment of total RNA, cDNA sunthesis and amplification procedure has been publised previously [19].

All duplicate measurements were analyse based on the Ct values of the PCR products. The delta-delta method, normalized with two reference genes (elongation-factor 1 and glyceraldehyde-3-phosphate dehydrogenase), were used to compare the relative expression results as follows: Relative expression (target gene, sample $\mathrm{x})=2^{\wedge}-(\Delta \mathrm{Ct}$ sample, sample $\mathrm{x}-\Delta \mathrm{Ct}$ calibrator, sample $\mathrm{x})=2^{-\Delta \Delta \mathrm{Ct}}[76]$. Here, the $\Delta \mathrm{Ct}$ calibrator represents the mean of the $\Delta \mathrm{Ct}$ values obtained for the tested gene. The delta threshold cycle $(\Delta \mathrm{Ct})$ is calculated as the difference in $\mathrm{Ct}$ for the target and reference genes. The relative stability of the GAPDH and EF-1 combination was confirmed using NormFinder [77]. PCR efficiency (E) was estimated for each primer pair by determining the slopes of standard curves obtained from serial dilution analysis of a cDNA to ensure that E ranged from 90 to $110 \%$. The primers used for amplification are listed in Additional file 1: Table S2. Wilcoxon non-parametric tests were used to compare relative expression between conditions, differences were considered significant when $p$-value $<0.01$. This complete list of primers is given in the supplementary file (Additional file 1: Table S3).

\section{Alternative gene splicing and exon usage}

To detect putative differential splicing variants, the reads were mapped on the scaffolds of the assembled draft genome, available for $P$. margaritifera. To reduce non-biological redundancy inherent to the current assembly state of the genome, only scaffolds with length $>3000 \mathrm{bp}$ were used for the mapping. From the 757,552 scaffolds initial set, only the 32,705 longest scaffolds were retained for downstream analysis, on which $37,662(92.7 \%)$ of the transcripts in our set could be positioned using the GMAP v2017-03-17 aligner with the default parameters for annotation [67]. Reads were mapped on the filtered reference genome using GSNAP v2017-03-17 aligner allowing five mismatches, splicing and using the 'splitting-output' function to retain only concordant and unique mapped paired-end reads [67]. We used the QORTs [78] and JunctionSeq $R$ packages [79] to 
detect significant differences in exon usage. Only exons and junctions with a minimal coverage of six were used for the analysis and only differences with FDR $<0.01$ were considered significant.

\section{Collection of specimens}

The collection of $P$. margaritifera followed institutional and national guidelines.

\section{Additional file}

Additional file 1: Figure S1. Summarized REVIGO semantic plot for gene ontology enrichment analysis. Figure S2. Relative gene expression for biomineralization genes analysed by qPCR in the pearl sac of $P$. margaritifera. Values are expressed as means of relative expression \pm standard deviation. Asterisks indicate significant differences (Wilcoxon test, $p$-value <0.01). Table S1. P. margaritifera individuals used for the transcriptome assembly. NA = Not identified. Table S2. Complete list and statistics on differentially expressed genes and their annotation. Table S3. Set of forward and reverse primers used for the biomineralization gene expression (real-time PCR) analysis in Pinctada margaritifera. (DOCX 795 kb)

\section{Abbreviations}

BMSP-like: Blue mussel shell protein-like; Pwap: Perlwapin; wfd18: Wap fourdisulfide core domain protein

\section{Acknowledgements}

The authors would especially like thank the host site, Pahai Poe Pearl Farm located in Apataki atoll (Tuamotu archipelago, French Polynesia) for their generous support, and D. Potin for his assistance with the cultured pearl photographs. The authors thank the Ifremer (Datarmor; RIC) and Station Biologique de Roscoff (ABiMS; http://abims.sb-roscoff.fr) bioinformatic platforms for providing computational resources and analysis support.

\section{Funding}

This study was supported by grants from the "Direction des Ressources Marines et Minières", through the AmeliGEN project (\# 10065/MEl/DRMM).

\section{Availability of data and materials}

Raw transcriptome sequences data have been deposited at NCBI (Bioproject: PRJNA449941). Genome and transcriptome assemblies will be made publicaly available upon acceptance of the manuscript. Codes for RNA-seq analysis are available upon request.

\section{Authors' contributions}

CLK conceived the study. NL, VQ conducted the pearl sac sampling and the RT-qPCR analysis, respectively. PA and JLL assembled the transcriptome. CR and JVD assembled the reference genome of $P$. margaritifera. $J L L$ analysed the RNAseq data. JLL and CLK wrote the paper. All co-authors contributed to reviewing the manuscript and accepted the final version for publication. All authors read and approved the final manuscript.

\section{Ethics approval and consent to participate}

The study was approved by the ethics committee of Ifremer.

\section{Consent for publication}

Not applicable.

\section{Competing interests}

The authors declare that they have no competing interests.

\section{Publisher's Note}

Springer Nature remains neutral with regard to jurisdictional claims in published maps and institutional affiliations.

\section{Author details}

'Ifremer, UMR 241 Ecosystèmes Insulaires Océaniens (EIO), Labex Corail, Centre Ifremer du Pacifique, BP 49, 98719 Tahiti, French Polynesia. ${ }^{2}$ Ifremer, UMR 5244 Interactions Hôtes-Pathogènes-Environnements, Université de Montpellier, Place Eugène Bataillon CC 80, 34095 Montpellier, France.

Received: 19 September 2018 Accepted: 9 January 2019

Published online: 06 February 2019

\section{References}

1. Taylor JJ, Strack E. Pearl production. In: Southgate PC, Lucas JS, editors. Pearl oyster. Amsterdam: Elsevier. p. 273-302.

2. Gervis $M H$, Sims NA. The biology and culture of pearl oysters (Bivalvia pteriidae). London: Manila: Overseas Development Administration of the United Kingdom; International Center for Living Aquatic Resources Management; 1992.

3. Kishore P, Southgate PC. A detailed description of pearl-sac development in the black-lip pearl oyster, Pinctada margaritifera (Linnaeus 1758). Aquac Res. 2016;47:2215-26 https://onlinelibrary.wiley.com/doi/epdf/10.1111/are.12674. Accessed 27 Jun 2018

4. Ky C-L, Blay C, Sham-Koua M, Vanaa V, Lo C, Cabral P. Family effect on cultured pearl quality in black-lipped pearl oyster Pinctada margaritifera and insights for genetic improvement. Aquat Living Resour. 2013;26:133-45. https://doi.org/10.1051/alr/2013055.

5. Ellis S, Haws M. Producing pearls using the black-lip pearl oyster (Pinctada margaritifera). Aquafarmer Inf Sheet. 1999:8.

6. Kvingedal R, Evans BS, Lind CE, Taylor JUU, Dupont-Nivet M, Jerry DR. Population and family growth response to different rearing location, heritability estimates and genotype $x$ environment interaction in the silverlip pearl oyster (Pinctada maxima). Aquaculture. 2010;304:1-6.

7. Jerry DR, Kvingedal R, Lind CE, Evans BS, Taylor JJU, Safari A. Donor-oyster derived heritability estimates and the effect of genotype $x$ environment interaction on the production of pearl quality traits in the silver-lipped pearl oyster, Pinctada maxima. Aquaculture. 2012;338-341:66-71.

8. McGinty E, Zenger KR, Taylor JU, Evans BS, Jerry DR. Diagnostic genetic markers unravel the interplay between host and donor oyster contribution in cultured pearl formation. Aquaculture. 2011:316:20-4.

9. McGinty EL, Evan BS, Taylor JUU, Jerry DR. Xenografts and pearl production in two pearl oyster species, P. Maxima and P. Margaritifera: effect on pearl quality and a key to understanding genetic contribution. Aquaculture. 2010; 302:175-81.

10. Blay C, Planes S, Ky C-L. Crossing phenotype heritability and candidate gene expression in grafted black-lipped pearl oyster Pinctada margaritifera, an animal chimera. J Heridity. 2018; in press.

11. Ky C-L, Okura R, Nakasai S, Devaux D. Quality trait signature at archipelago scale of the cultured pearls produced by the black-lipped pearl oyster (Pinctada margaritifera Var. cumingi) in French Polynesia. J Shellfish Res. 2016;35:827-35

12. Latchere O, Le Moullac G, Gaertner-Mazouni N, Fievet J, Magré K, Saulnier D. Influence of preoperative food and temperature conditions on pearl biogenesis in Pinctada margaritifera. Aquaculture. 2017;479 Supplement C: 176-87. https://doi.org/10.1016/j.aquaculture.2017.05.046.

13. Li S, Huang J, Liu C, Liu Y, Zheng G, Xie L, et al. Interactive effects of seawater acidification and elevated temperature on the transcriptome and biomineralization in the pearl oyster Pinctada fucata. Environ Sci Technol. 2016;50:1157-65. https://doi.org/10.1021/acs.est.5b05107.

14. Gueguen Y, Czorlich Y, Mastail M, Le Tohic B, Defay D, Lyonnard P, et al. $Y$ Yes, it turns: experimental evidence of pearl rotation during its formation. $R$ Soc Open Sci. 2015:2:150144. https://doi.org/10.1098/rsos.150144.

15. Tayalé A, Gueguen Y, Treguier C, Grand JL, Cochennec-Laureau N, Montagnani $\mathrm{C}$, et al. Evidence of donor effect on cultured pearl quality from a duplicated grafting experiment on Pinctada margaritifera using wild donors. Aquat Living Resour. 2012;25:269-80. https://doi.org/10.1051/alr/2012034.

16. Ky C-L, Blay C, Sham-Koua M, Lo C, Cabral P. Indirect improvement of pearl grade and shape in farmed Pinctada margaritifera by donor "oyster" selection for green pearls. Aquaculture. 2014;432 Supplement C:154-62. https://doi.org/10.1016/j.aquaculture.2014.05.002

17. Blay C, Sham-Koua M, Vonau V, Tetumu R, Cabral P, Ky C-L. Influence of nacre deposition rate on cultured pearl grade and colour in the black lipped pearl oyster Pinctada margaritifera using farmed donor families. Aquac Int. 2014;22:937-53. https://doi.org/10.1007/s10499-013-9719-5. 
18. Ky C-L, Blay C, Aiho V, Cabral P, Le Moullac G, Lo C. Macro-geographical differences influenced by family-based expression on cultured pearl grade, shape and colour in the black-lip 'pearl oyster' Pinctada margaritifera: a preliminary bi-local case study in French Polynesia. Aquac Res. 2017:48:27082. https://doi.org/10.1111/are.12880.

19. Blay C, Planes S, Ky C-L. Optimal age of the donor graft tissue in relation to cultured pearl phenotypes in the mollusc, Pinctada margaritifera. PLOS ONE. 2018;13:e0198505. https://doi.org/10.1371/ journal.pone.0198505.

20. Ky C-L, Nakasai S, Parrad S, Broustal F, Devaux D, Louis P. Variation in cultured pearl quality traits in relation to position of saibo cutting on the mantle of black-lipped pearl oyster Pinctada margaritifera. Aquaculture. 2018;493:85-92. https://doi.org/10.1016/j.aquaculture.2018.04.059.

21. Ky C-L, Molinari N, Moe E, Pommier S. Impact of season and grafter skill on nucleus retention and pearl oyster mortality rate in Pinctada margaritifera aquaculture. Aquac Int. 2014;22:1689-701. https://doi.org/ 10.1007/s10499-014-9774-6.

22. Lemer S, Saulnier D, Gueguen Y, Planes S. Identification of genes associated with shell color in the black-lipped pearl oyster, Pinctada margaritifera. BMC Genomics. 2015;16.

23. Jones DB, Jerry DR, Foret S, Konovalov D, Zenger KR. Genome-wide SNP validation and mantle tissue transcriptome analysis in the silver-lipped pearl oyster, Pinctada maxima. Mar Genomics. 2013;15:647-58.

24. Jones DB, Jerry DR, Khatkar MS, Raadsma HW, Zenger KR. A high-density SNP genetic linkage map for the silver-lipped pearl oyster, Pinctada maxima: a valuable resource for gene localisation and marker-assisted selection. BMC Genomics. 2013;14:810. https:/doi.org/10.1186/1471-2164-14-810.

25. Jones DB, Jerry DR, Khatkar MS, Moser G, Raadsma HW, Taylor JJ, et al. Quantitative trait loci and genetic association analysis reveals insights into complex pearl quality traits in donor silver-lipped pearl oysters. Aquaculture. 2014;434:476-85. https://doi.org/10.1016/j.aquaculture.2014.08.038.

26. Inoue $\mathrm{N}$, Ishibashi $\mathrm{R}$, Ishikawa $\mathrm{T}$, Atsumi T, Aoki H, Komaru A. Comparison of expression patterns of shell matrix protein genes in the mantle tissues between high- and low-quality pearl-producing recipients of the pearl oyster, Pinctada fucata. Zoolog Sci. 2011;28:32-6. https://doi.org/10.2108/zsj.28.32.

27. Inoue N, Ishibashi R, Ishikawa T, Atsumi T, Aoki H, Komaru A. Can the quality of pearls from the Japanese pearl oyster (Pinctada fucata) be explained by the gene expression patterns of the major shell matrix proteins in the pearl sac? Mar Biotechnol N Y N. 2011;13:48-55. https:// doi.org/10.1007/s10126-010-9267-1.

28. Blay C, Planes S, Ky C-L. Cultured pearl surface quality profiling by the shell matrix protein gene expression in the biomineralised pearl sac tissue of Pinctada margaritifera. Mar Biotechnol. 2018;in press.

29. Marie B, Joubert C, Tayalé A, Zanella-Cléon I, Belliard C, Piquemal D, et al. Different secretory repertoires control the biomineralization processes of prism and nacre deposition of the pearl oyster shell. Proc Natl Acad Sci. 2012;109:20986-91. https://doi.org/10.1073/pnas.1210552109.

30. Marie B, Jackson DJ, Ramos-Silva P, Zanella-Cléon I, Guichard N, Marin F. The shell-forming proteome of Lottia gigantea reveals both deep conservations and lineage-specific novelties. FEBS J. 280:214-32. https:// doi.org/10.1111/febs.12062.

31. Isowa Y, Sarashina I, Setiamarga DHE, Endo K. A comparative study of the shell matrix protein aspein in pterioid bivalves. J Mol Evol. 2012;75:11-8. https://doi.org/10.1007/s00239-012-9514-3.

32. Takeuchi T, Sarashina I, lijima M, Endo K. In vitro regulation of $\mathrm{CaCO} 3$ crystal polymorphism by the highly acidic molluscan shell protein Aspein. FEBS Lett. 2008;582:591-6. https://doi.org/10.1016/j.febslet.2008.01.026.

33. Tsukamoto D, Sarashina I, Endo K. Structure and expression of an unusually acidic matrix protein of pearl oyster shells. Biochem Biophys Res Commun. 2004;320:1175-80. https://doi.org/10.1016/j.bbrc.2004.06.072.

34. Elhadj S, Yoreo JJD, Hoyer JR, Dove PM. Role of molecular charge and hydrophilicity in regulating the kinetics of crystal growth. Proc Natl Acad Sci. 2006;103:19237-42. https://doi.org/10.1073/pnas.0605748103.

35. Shi $Y$, He M. Differential gene expression identified by RNA-Seq and $q P C R$ in two sizes of pearl oyster (Pinctada fucata). Gene. 2014;538:313-22. https:// doi.org/10.1016/j.gene.2014.01.031.

36. Li S, Liu C, Huang J, Liu Y, Zhang S, Zheng G, et al. Transcriptome and biomineralization responses of the pearl oyster Pinctada fucata to elevated $\mathrm{CO}_{2}$ and temperature. Sci Rep. 2016;6:18943. https://doi.org/10.1038/ srep18943.
37. Zhao X, Wang $Q$, Jiao $Y$, Huang $R$, Deng $Y$, Wang $H$, et al. Identification of genes potentially related to biomineralization and immunity by transcriptome analysis of pearl sac in pearl oyster Pinctada martensii. Mar Biotechnol. 2012;14:730-9. https://doi.org/10.1007/s10126-012-9438-3.

38. Shi Y, Yu C, Gu Z, Zhan X, Wang Y, Wang A. Characterization of the pearl oyster (Pinctada martensii) mantle transcriptome unravels biomineralization genes. Mar Biotechnol. 2013;15:175-87. https://doi.org/10.1007/s10126-012-9476-X.

39. Li H, Liu B, Huang G, Fan S, Zhang B, Su J, et al. Characterization of transcriptome and identification of biomineralization genes in winged pearl oyster (Pteria penguin) mantle tissue. Comp Biochem Physiol Part D Genomics Proteomics. 2017;21:67-76. https://doi.org/10.1016/j.cbd.2016.12.002.

40. Joubert C, Piquemal D, Marie B, Manchon L, Pierrat F, Zanella-Cléon I, et al. Transcriptome and proteome analysis of Pinctada margaritifera calcifying mantle and shell: focus on biomineralization. BMC Genomics. 2010;11:613. https://doi.org/10.1186/1471-2164-11-613.

41. Teaniniuraitemoana V, Huvet A, Levy P, Klopp C, Lhuillier E, GaertnerMazouni N, et al. Gonad transcriptome analysis of pearl oyster Pinctada margaritifera: identification of potential sex differentiation and sex determining genes. BMC Genomics. 2014;15:491. https://doi.org/10.1186/ 1471-2164-15-491.

42. Huang $X-D$, Zhao M, Liu W-G, Guan $Y-Y$, Shi $Y$, Wang Q, et al. Gigabase-scale transcriptome analysis on four species of pearl oysters. Mar Biotechnol. 2013;15:253-64.

43. Marin F, Luquet G, Marie B, Medakovic D. Molluscan shell proteins: primary structure, origin, and evolution. Curr Top Dev Biol. 2008;80:209-76. https:// doi.org/10.1016/S0070-2153(07)80006-8.

44. Marie B, Arivalagan J, Mathéron L, Bolbach G, Berland S, Marie A, et al. Deep conservation of bivalve nacre proteins highlighted by shell matrix proteomics of the Unionoida Elliptio complanata and Villosa lienosa. J R Soc Interface. 2017;14:20160846. https://doi.org/10.1098/rsif.2016.0846.

45. Kocot KM, Aguilera F, McDougall C, Jackson DJ, Degnan BM. Sea shell diversity and rapidly evolving secretomes: insights into the evolution of biomineralization. Front Zool. 2016;13:23. https://doi.org/10.1186/s12983-016-0155-z

46. Bahn SY, Jo BH, Choi YS, Cha HJ. Control of nacre biomineralization by Pif80 in pearl oyster. Sci Adv. 2017;3.

47. Gu Z, Yin X, Yu C, Zhan X, Shi Y, Wang A. Expression profiles of nine biomineralization genes and their relationship with pearl nacre thickness in the pearl oyster, Pinctada fucata martensii dunker. Aquac Res. 2016;47:187484. https://doi.org/10.1111/are.12645.

48. Arivalagan J, Yarra T, Marie B, Sleight VA, Duvernois-Berthet E, Clark MS, et al. Insights from the Shell proteome: biomineralization to adaptation. Mol Biol Evol. 2017;34:66-77. https://doi.org/10.1093/molbev/msw219.

49. Jackson DJ, McDougall C, Woodcroft B, Moase P, Rose RA, Kube M, et al. Parallel evolution of nacre building gene sets in molluscs. Mol Biol Evol. 2010:27:591-608.

50. Wang X, Liu Z, Wu W. Transcriptome analysis of the freshwater pearl mussel (Cristaria plicata) mantle unravels genes involved in the formation of shell and pearl. Mol Genet Genomics MGG. 2017;292:343-52.

51. Li S, Liu Y, Huang J, Zhan A, Xie L, Zhang R. The receptor genes PfBMPR1B and PfBAMBI are involved in regulating shell biomineralization in the pearl oyster Pinctada fucata. Sci Rep. 2017;7.

52. Joubert C, Linard C, Moullac GL, Soyez C, Saulnier D, Teaniniuraitemoana $\mathrm{V}$, et al. Temperature and food influence shell growth and mantle gene expression of shell matrix proteins in the pearl oyster Pinctada margaritifera. PLoS One. 2014;9:e103944. https:// doi.org/10.1371/journal.pone.0103944.

53. Blay C, Parrad S, Cabral P, Aiho V, Ky C-L. Correlations between cultured pearl size parameters and PIF-177 biomarker expression in Pinctada margaritifera families reared in two contrasting environments. Estuar Coast Shelf Sci. 2016;182 Part B:254-60. https://doi.org/10.1016/j.ecss.2016.05.020.

54. Feng D, Li Q, Yu H, Kong L, Du S. Identification of conserved proteins from diverse shell matrix proteome in Crassostrea gigas: characterization of genetic bases regulating shell formation. Sci Rep. 2017;7:45754. https://doi. org/10.1038/srep45754

55. Suzuki M, Saruwatari K, Kogure T, Yamamoto Y, Nishimura T, Kato T, et al. An acidic matrix protein, Pif, is a key macromolecule for nacre formation. Science. 2009;325:1388-90. https://doi.org/10.1126/science.1173793.

56. Livingston BT, Killian CE, Wilt F, Cameron A, Landrum MJ, Ermolaeva O, et al. A genome-wide analysis of biomineralization-related proteins in the sea urchin Strongylocentrotus purpuratus. Dev Biol. 2006:300:335-48. https://doi. org/10.1016/j.ydbio.2006.07.047. 
57. Chuong EB, Elde NC, Feschotte C. Regulatory activities of transposable elements: from conflicts to benefits. Nat Rev Genet. 2017;18:71-86. https:// doi.org/10.1038/nrg.2016.139.

58. Hirsch CD, Springer NM. Transposable element influences on gene expression in plants. Biochim Biophys Acta BBA - Gene Regul Mech. 1860; 2017:157-65. https://doi.org/10.1016/j.bbagrm.2016.05.010.

59. Trizzino M, Park Y, Holsbach-Beltrame M, Aracena K, Mika K, Caliskan M, et al. Transposable elements are the primary source of novelty in primate gene regulation. Genome Res. 2017:gr.218149.116. https://doi. org/10.1101/gr.218149.116.

60. Ahmed M, Liang P. Transposable elements are a significant contributor to tandem repeats in the Human genome. Comparative and Functional Genomics; 2012

61. Sharma A, Wolfgruber TK, Presting GG. Tandem repeats derived from centromeric retrotransposons. BMC Genomics. 2013;14:142. https:/doi.org/ 10.1186/1471-2164-14-142.

62. Liu J, Yang D, Liu S, Li S, Xu G, Zheng G, et al. Microarray: a global analysis of biomineralization-related gene expression profiles during larval development in the pearl oyster, Pinctada fucata. BMC Genomics. 2015;16. https://doi.org/10.1186/s12864-015-1524-2.

63. Bolger AM, Lohse M, Usadel B. Trimmomatic: a flexible trimmer for Illumina sequence data. Bioinformatics. 2014;15:2114-20. https://doi.org/10.1093/ bioinformatics/btu170.

64. Haas BJ, Papanicolaou A, Yassour M, Grabherr M, Blood PD, Bowden J, et al. De novo transcript sequence reconstruction from RNA-seq using the trinity platform for reference generation and analysis. Nat Protoc. 2013;8:1494-512.

65. Simão FA, Waterhouse RM, loannidis P, Kriventseva EV, Zdobnov EM. BUSCO: assessing genome assembly and annotation completeness with single-copy orthologs. Bioinformatics. 2015;31:3210-2.

66. Smith-Unna R, Boursnell C, Patro R, Hibberd JM, Kelly S. TransRate: reference-free quality assessment of de novo transcriptome assemblies. Genome Res. 2016;26:1134-44.

67. Wu TD, Reeder J, Lawrence M, Becker G, Brauer MJ. GMAP and GSNAP for genomic sequence alignment: enhancements to speed, accuracy, and functionality. Statistical Genomics: Methods and Protocols. 2016:283-334.

68. Bairoch A, Apweiler R. The SWISS-PROT protein sequence database and its supplement TrEMBL in 2000. Nucleic Acids Res. 2000;28:45-8 http://www. ncbi.nlm.nih.gov/pmc/articles/PMC102476/. Accessed 20 Dec 2016.

69. Altschul SF, Madden TL, Schäffer AA, Zhang J, Zhang Z, Miller W, et al. Gapped BLAST and PSI-BLAST: a new generation of protein database search programs. Nucleic Acids Res. 1997;25:3389-402.

70. Ky C-L, Lau C, Koua MS, Lo C. Growth performance comparison of Pinctada margaritifera juveniles produced by thermal dhock or gonad scarification spawning procedures. J Shellfish Res. 2015;34:811-7.

71. McGinty EL, Zenger KR, Jones DB, Jerry DR. Transcriptome analysis of biomineralisation-related genes within the pearl sac: host and donor oyster contribution. Mar Genomics. 2012;5:27-33.

72. Li H, Handsaker B, Wysoker A, Fennell T, Ruan J, Homer N, et al. The sequence alignment/map format and SAMtools. Bioinformatics. 2009;25:2078-9.

73. Anders S, Pyl PT, Huber W. HTSeq - a Python framework to work with highthroughput sequencing data. Bioinformatics. 2015;31:166-9.

74. Love Ml, Huber W, Anders S. Moderated estimation of fold change and dispersion for RNA-seq data with DESeq2. Genome Biol. 2014;15:550

75. Klopfenstein DV, Zhang L, Pedersen BS, Ramírez F, Warwick Vesztrocy A, Naldi A, et al. GOATOOLS: a Python library for gene ontology analyses. Sci Rep. 2018;8:10872. https://doi.org/10.1038/s41598-018-28948-z.

76. Livak KJ, Schmittgen TD. Analysis of relative gene expression data using real-time quantitative PCR and the 2(-Delta Delta C(T)) method. Methods San Diego Calif. 2001:25:402-8. https://doi.org/10.1006/meth.2001.1262

77. Andersen CL, Jensen JL, Ørntoft TF. Normalization of real-time quantitative reverse transcription-PCR data: a model-based variance estimation approach to identify genes suited for normalization, applied to bladder and colon cancer data sets. Cancer Res. 2004;64:5245-50

78. Hartley SW, Mullikin JC. QoRTs: a comprehensive toolset for quality control and data processing of RNA-Seq experiments. BMC Bioinformatics. 2015;16

79. Hartley SW, Mullikin JC. Detection and visualization of differential splicing in RNA-Seq data with JunctionSeq. Nucleic Acids Res. 2016;44:15. https://doi. org/10.1093/nar/gkw501

\section{Ready to submit your research? Choose BMC and benefit from:}

- fast, convenient online submission

- thorough peer review by experienced researchers in your field

- rapid publication on acceptance

- support for research data, including large and complex data types

- gold Open Access which fosters wider collaboration and increased citations

- maximum visibility for your research: over $100 \mathrm{M}$ website views per year

At BMC, research is always in progress.

Learn more biomedcentral.com/submissions 